\title{
Physiological Indices and Growth of Castor Bean Irrigated With Waters of Different Cationic Nature
}

\author{
Geovani S. de Lima ${ }^{1}$, Hans R. Gheyi ${ }^{2}$, Reginaldo G. Nobre ${ }^{3}$, Lauriane A. dos A. Soares ${ }^{1}$, Leandro de P. Souza ${ }^{4}$, \\ Francisco Wesley A. Pinheiro ${ }^{4}$, Adaan S. Dias ${ }^{4} \&$ Sabrina G. de Oliveira ${ }^{1}$ \\ ${ }^{1}$ Center of Science and Agri-food Technology, Federal University of Campina Grande, Pombal, Brazil \\ ${ }^{2}$ Nucleus of Soil and Water Engineering, Federal University of Recôncavo of Bahia, Cruz das Almas, Brazil \\ ${ }^{3}$ Department of Science and Technology, Federal Rural University of Semiarid, Caraúbas, Brazil \\ ${ }^{4}$ Academic Unit of Agricultural Engineering, Federal University of Campina Grande, Campina Grande, Brazil \\ Correspondence: Geovani S. de Lima, Center of Science and Agri-food Technology, Federal University of \\ Campina Grande, Pombal, Brazil. Tel: 55-0839-9945-9864. E-mail: geovanisoareslima@gmail.com
}

Received: July 12, 2018 Accepted: August 10, $2018 \quad$ Online Published: September 15, 2018

doi:10.5539/jas.v10n10p405 URL: https://doi.org/10.5539/jas.v10n10p405

\begin{abstract}
It was proposed, in the present study, to evaluate the gas exchange and the growth of the castor bean cv. BRS Energia due to the isolated or mixed cationic nature of irrigation water. The study was conducted in drainage lysimeters under greenhouse conditions, using an Eutrophic Greyish Argissolo with a sandy-loam texture in the municipality of Campina Grande, Brazil. A randomized block design was used with six cationic composition of irrigation water $\left(\mathrm{S}_{1}\right.$-control, $\mathrm{S}_{2}-\mathrm{Na}^{+}, \mathrm{S}_{3}-\mathrm{Ca}^{2+}, \mathrm{S}_{4}-\mathrm{Na}^{+}+\mathrm{Ca}^{2+}, \mathrm{S}_{5}-\mathrm{K}^{+}$and $\mathrm{S}_{6}-\mathrm{Na}^{+}+\mathrm{Ca}^{2+}+\mathrm{Mg}^{2+}$ with four replicates, each composed of five plants. The plants under the control treatment were submitted to irrigation with low salinity water $\left(\mathrm{ECw}=0.6 \mathrm{dS} \mathrm{m}^{-1}\right)$ and the remaining treatments were irrigated with $\mathrm{ECw}$ of $4.5 \mathrm{dS} \mathrm{m}^{-1}$ prepared with salts of different cations in chloride form. The gas exchanges and the growth of the castor bean cv. BRS Energy were determined at 100 days after sowing. The gas exchanges and the growth of the castor $\mathrm{cv}$. BRS Energy were more sensitive to the variation in the electrical conductivity of the water compared to the cationic nature of the water, being the least deleterious effect observed in the plants irrigated with potassic water. The plants irrigated with water of potassium composition obtained the highest values for stomatal conductance, transpiration and rate of assimilation of $\mathrm{CO}_{2}$; at 100 days after sowing; the castor bean $\mathrm{cv}$. BRS Energia showed sensitivity to the presence of sodium and calcium salts in irrigation water.
\end{abstract}

Keywords: Ricinus communis L., irrigation, salinity

\section{Introduction}

The castor bean crop (Ricinus communis L.), a species of the Euphorbiaceae family, stands out as a profitable agricultural option for cultivation in the Northeast of Brazil, due to its characteristics of xerophilism and heliophilia and adaptation to various edaphoclimatic conditions (Ribeiro et al., 2009). Castor oil, obtained by the extraction of seeds, has several applications in the industrial area, and can be used in the manufacture of paints, dyes, disinfectants, germicides, low temperature lubricating oils, glues and adhesives, and as a byproduct cake after obtaining the oil, which has great potential as an organic manure, which can be used in crop fertilization (Silva \& Martins, 2009; Silva et al., 2012).

In semiarid areas of the Brazilian Northeast, the occurrence of water scarcity and irregularity in the distribution of rainfall is common, and evapotranspiration is higher than precipitation in most part of the year. Therefore, the assured establishment of crops in this region depends necessarily on irrigation. However, most of the available water resources have high salt concentrations (Nobre et al., 2011). In the water intended for irrigation, the cationic composition depends on geological nature (lithologic composition), water source and path traveled, being easily found waters rich in sodium, calcium and magnesium, and in some cases, potassium (Medeiros et al., 2003).

Quantitative and qualitative scarcity of water resources has led to the search for alternatives for efficient water use and rational utilization of waters considered as of inferior quality since their use is almost obligatory in the agriculture of semi-arid regions (Alves et al., 2011). In this context, several authors have studied the effect of 
irrigation with waters of different salinity levels on castor bean cultivation (Cavalcanti et al., 2005; Alves et al., 2012; Nobre et al., 2013; Santos et al., 2013; Lima et al., 2014a, 2014b).

However, these studies were limited to the use of different levels of water salinity on the cultivation of this oilseed crop. Thus, conducting research that seeks to identify the cation that provides the greatest or least deleterious effect on the crop is extremely important for its establishment in the Brazilian semi-arid region. Lima et al. (2016) in a study evaluating the morphophysiology of the castor bean cv. BRS Energy at 80 days after sowing and oil content, as a function of the irrigation with waters of different electrical conductivity and cationic compositions [control-ECW $=0.6 \mathrm{dS} \mathrm{m}{ }^{-1}, \mathrm{Na}^{+}, \mathrm{Ca}^{2+}, \mathrm{Na}^{+}+\mathrm{Ca}^{2+} ; \mathrm{K}^{+}$and $\mathrm{Na}^{+}+\mathrm{Ca}^{2+}+\mathrm{Mg}^{2+}\left(\mathrm{ECW}=4.5 \mathrm{dS} \mathrm{m}^{-1}\right)$ ], concluded that gas exchange, growth and oil yield were more affected by $\mathrm{ECW}$ variation than by cationic nature of water. Sousa Júnior et al. (2017) evaluating the gas exchange and production of sunflower cv. BRS 324 under irrigation with water of different cationic nature and salinity [control-ECw $=0.5 \mathrm{dS} \mathrm{m}^{-1}, \mathrm{NaCl}, \mathrm{CaCl}_{2}, \mathrm{KCl}$ and $\left.\mathrm{NaCl}+\mathrm{CaCl}_{2}+\mathrm{MgCl}_{2}\left(\mathrm{ECW}=5.0 \mathrm{dS} \mathrm{m}{ }^{-1}\right)\right]$ also verified that the greatest decrease occurred in gas exchanges due to the variation in the $\mathrm{ECw}$ of the irrigation water.

Since most crops exploited in the semi-arid region are classified as sensitive to moderately sensitive to salinity, there emerges the urgent need to better characterize these waters to establish adequate management for plants, soil and irrigation systems (Medeiros et al., 2003). In this context, the aim of this study was to evaluate the gas exchange and the growth of the castor bean cv. BRS Energy as a function of salinity and cationic composition of irrigation water 100 days after sowing during the fruiting phase of the crop.

\section{Material and Methods}

\subsection{Characterization of the Experimental Area and Treatments}

The experiment was conducted in drainage lysimeters in a greenhouse at the Center of Technology and Natural Resources of the Federal University of Campina Grande (CTRN/UFCG), located in the municipality of Campina Grande, PB, Brazil, at the local geographic coordinates $7^{\circ} 15^{\prime} 18^{\prime \prime} \mathrm{S}, 35^{\circ} 52^{\prime} 28^{\prime \prime} \mathrm{W}$ and mean altitude of $550 \mathrm{~m}$. It should be emphasized that this work is a continuation of results reported earlier by Lima et al. (2016 on growth variables at 80 days of cultivation and oil content at 100 days after sowing.

Treatments consisted of six cationic compositions of irrigation water $\left(\mathrm{S}_{1}\right.$-control; $\mathrm{S}_{2}-\mathrm{Na}^{+} ; \mathrm{S}_{3}-\mathrm{Ca}^{2+} ; \mathrm{S}_{4}-\mathrm{Na}^{+}+\mathrm{Ca}^{2+}$; $\mathrm{S}_{5}-\mathrm{K}^{+}$and $\mathrm{S}_{6}-\mathrm{Na}^{+}+\mathrm{Ca}^{2+}+\mathrm{Mg}^{2+}$ ), in such a way to have equivalent proportions of $1: 1$ for $\mathrm{Na}: \mathrm{Ca}$ and $7: 2: 1$ for $\mathrm{Na}: \mathrm{Ca}: \mathrm{Mg}$, respectively. Plants in the control treatment $\left(\mathrm{S}_{1}\right)$ were irrigated using water with electrical conductivity $(\mathrm{ECW})$ of $0.6 \mathrm{dS} \mathrm{m}^{-1}$, whereas the plants in other treatments $\left(\mathrm{S}_{2} ; \mathrm{S}_{3} ; \mathrm{S}_{4} ; \mathrm{S}_{5}\right.$ and $\left.\mathrm{S}_{6}\right)$ were irrigated using water with $\mathrm{ECw}$ of $4.5 \mathrm{dS} \mathrm{m}^{-1}$, prepared with different cations, in chloride form. The experiment was set up in randomized block design with six treatments and four replicates, totaling 24 experimental plots, each one composed of five plants.

\subsection{Cultivar, Installation and Conduction of the Experiment}

Castor bean cv. BRS Energia was studied. This cultivar stands out for its physiological vigor, precoce cycle (120 to 150 days), small size, semi-indiscriminate fruits (allows a single harvest), conical clusters with a mean size of $60 \mathrm{~cm}$, oil content in the seeds on average $48 \%$ (Silva et al., 2009).

Plants were grown in drainage lysimeters with capacity for $100 \mathrm{~L}(50 \mathrm{~cm}$ high, $30 \mathrm{~cm}$ bottom diameter and 33 $\mathrm{cm}$ upper diameter), perforated at the base to allow drainage and attached to a 4-mm-diameter drain. The tip of the drain inside the lysimeter was involved with nonwoven geotextile (Bidim OP 30) and a plastic container was placed below each drain to collect the drained water.

The lysimeters were filled with a $2 \mathrm{~kg}$ layer of crushed stone (no. zero), followed by $54 \mathrm{~kg}$ of soil material (properly pounded to break up clods and homogenized), and $76 \mathrm{~kg}$ of the same soil mixed with $1.70 \mathrm{~kg}$ of earthworm humus per lysimeter to reach $1 \%$ of organic matter based on total weight. The soil used in the experiment was collected in the 0-30 cm layer (A horizon) of an Eutrophic Grey Argisol, from the district of São José da Mata (Campina Grande-PB).

Based on soil analysis data, acidity was corrected by adding $49.25 \mathrm{~g}$ of dolomitic limestone to the soil of each lysimeter (130 kg of soil), the amount necessary to neutralize $\mathrm{Al}^{3+}$ and to increase exchangeable $\mathrm{Ca}^{2+}$ and $\mathrm{Mg}^{2+}$ contents to $70 \%$. After acidity correction, the soil showed the following chemical characteristics: $\mathrm{Ca}^{2+}=1.14$ $\mathrm{cmol}_{\mathrm{c}} \mathrm{kg}^{-1} ; \mathrm{Mg}^{2+}=1.36 \mathrm{cmol}_{\mathrm{c}} \mathrm{kg}^{-1} ; \mathrm{Na}^{+}=0.30 \mathrm{cmol}_{\mathrm{c}} \mathrm{kg}^{-1} ; \mathrm{K}^{+}=0.14 \mathrm{cmol}_{\mathrm{c}} \mathrm{kg}^{-1} ; \mathrm{H}^{+}=0.11 \mathrm{cmol}_{\mathrm{c}} \mathrm{kg}^{-1} ; \mathrm{Al}^{3+}=0$ $\mathrm{cmol}_{\mathrm{c}} \mathrm{kg}^{-1} ; \mathrm{CEC}=3.05 \mathrm{cmol}_{\mathrm{c}} \mathrm{kg}^{-1} ;$ Organic matter $=1.08 \mathrm{dag} \mathrm{kg}^{-1} ; \mathrm{P}=47.80 \mathrm{mg} \mathrm{kg}^{-1}$ and $\mathrm{pH}$ in water $(1: 2.5)=$ 6.42 . 
Water salinity levels were obtained by dissolving sodium chloride $(\mathrm{NaCl})$, calcium chloride $\left(\mathrm{CaCl}_{2} \cdot 2 \mathrm{H}_{2} \mathrm{O}\right)$, magnesium chloride $\left(\mathrm{MgCl}_{2} \cdot 6 \mathrm{H}_{2} \mathrm{O}\right)$ and potassium chloride $(\mathrm{KCl})$ in the irrigation water according to the preestablished treatments in water from the local supply system. The amount of salt to be added was calculated according to the equation of Richards (1954), considering the relationship between ECw and concentration of salts $\left.\left(10 * \mathrm{mmol}_{\mathrm{c}} \mathrm{L}^{-1}=1 \mathrm{dS} \mathrm{m}\right)^{-1}\right)$.

Before sowing, the water volume required for the soil to reach field capacity was determined by capillary saturation followed by drainage. After the soil was brought to field capacity, using the respective waters according to the treatment, sowing was carried out using 10 seeds of 'BRS Energia' castor bean per lysimeter, at $2 \mathrm{~cm}$ depth and equidistantly distributed. At 10 days after sowing (10 DAS), thinning was performed to leave only one plant per recipient.

The soil was kept at field capacity by daily irrigations, applying in each lysimeter the water corresponding to the treatment. The applied water volume was determined according to the water needs of the plants, estimated by water balance: water volume applied minus water volume drained in the previous irrigation, plus a leaching fraction of 0.10, according to studies conducted previously (Nobre et al., 2013).

Fertilizations with nitrogen, potassium and phosphorus were carried out based on the recommendations of Novais et al. (1991), using $40.62 \mathrm{~g}$ of potassium nitrate and $75 \mathrm{~g}$ of monoammonium phosphate. These quantities corresponded to 100,150 and $300 \mathrm{mg} \mathrm{kg}^{-1}$ of soil of $\mathrm{N}, \mathrm{K}_{2} \mathrm{O}$ and $\mathrm{P}_{2} \mathrm{O}_{5}$, respectively, and were applied as top-dressing in four equal split doses through fertigation, at 10-day intervals, with the first one at 15 DAS. To meet probable deficiencies of micronutrients, castor bean leaves were sprayed with $7 \mathrm{~L}$ of a solution containing $2.5 \mathrm{~g} \mathrm{~L}^{-1}$ of Ubyfol [(N (15\%); $\mathrm{P}_{2} \mathrm{O}_{5}(15 \%) ; \mathrm{K}_{2} \mathrm{O}$ (15\%); $\mathrm{Ca}(1 \%) ; \mathrm{Mg}(1.4 \%) ; \mathrm{S}$ (2.7\%); $\mathrm{Zn} \mathrm{(0.5 \% );} \mathrm{B} \mathrm{(0.05 \% );}$ $\mathrm{Fe}(0.5 \%) ; \mathrm{Mn}(0.05 \%) ; \mathrm{Cu}(0.5 \%) ; \mathrm{Mo}(0.02 \%)]$ at 30 and 60 DAS.

\subsection{Variables Measured}

At 100 after sowing, the gas exchanges were evaluated: stomatal conductance (gs), transpiration (E), internal $\mathrm{CO}_{2}$ concentration (Ci), $\mathrm{CO}_{2}$ assimilation rate (A) and growth: plant height (PH), stem diameter (SD) leaf area (LA). The stomatal conductance - gs $\left(\mathrm{mol} \mathrm{H}_{2} \mathrm{O} \mathrm{m}^{-2} \mathrm{~s}^{-1}\right)$, transpiration-E $\left(\mathrm{mmol} \mathrm{H}_{2} \mathrm{O} \mathrm{m}^{-2} \mathrm{~s}^{-1}\right)$, the assimilation rate of $\mathrm{CO}_{2}-\mathrm{A}\left(\mu \mathrm{mol} \mathrm{m} \mathrm{m}^{-2} \mathrm{~s}^{-1}\right)$ and the internal $\mathrm{CO}^{2}$-Ci concentration $\left(\mu \mathrm{mol} \mathrm{m} \mathrm{m}^{-2} \mathrm{~s}^{-1}\right)$ were evaluated on the third leaf counted from the apex, using the portable equipment "LCPro +" from ADC BioScientific Ltd.

Plant height was obtained considering the distance from collar to apical meristem. Stem diameter was measured at $5 \mathrm{~cm}$ from plant collar. Leaf area was obtained by measuring the midrib length of all leaves, following the methodology described by Severino et al. (2005), according to Equation 1:

$$
\mathrm{S}=\Sigma 0.26622 \times \mathrm{P}^{2.4248}
$$

where, S: total leaf area of the plant $\left(\mathrm{cm}^{2}\right)$; P: leaf midrib length $(\mathrm{cm})$.

The phytosanitary control during the conduction of the research consisted of weeding, superficial scarification of the soil before each irrigation event and plant stewardship, in order to avoid the tipping of the same. The insecticides of the chemical group Neonicotinoid $\left(5.4 \mathrm{~g} \mathrm{~L}^{-1}\right)$, fungicide of the chemical group Triazole $\left(7.0 \mathrm{~g} \mathrm{~L}^{-1}\right)$ and acaricide $\left(3.5 \mathrm{~g} \mathrm{~L}^{-1}\right)$ belonging to the chemical group Abamectin were applied.

\subsection{Statistical Analysis}

At the end of this research, the data collected were analyzed through analysis of variance by ' $F$ ' test; when a significant difference for the source of variation occurred, the test of comparison of means and the contrasts between the means of the treatments (Tukey at 0.05 of probability) were performed using the statistical software SISVAR-ESAL (FERREIRA, 2011). The following orthogonal contrasts were established: $\hat{\mathrm{y}}_{1}\left(\mathrm{~S}_{1}\right.$ vs. $\mathrm{S}_{2} ; \mathrm{S}_{3} ; \mathrm{S}_{4}$; $\left.\mathrm{S}_{5} ; \mathrm{S}_{6}\right) ; \hat{y}_{2}\left(\mathrm{~S}_{2} v s . \mathrm{S}_{3}\right) ; \hat{\mathrm{y}}_{3}\left(\mathrm{~S}_{2} v s . \mathrm{S}_{6}\right) ; \hat{\mathrm{y}}_{4}\left(\mathrm{~S}_{2} v s . \mathrm{S}_{5}\right) ; \hat{\mathrm{y}} 5\left(\mathrm{~S}_{5} v s . \mathrm{S}_{2}, \mathrm{~S}_{3}, \mathrm{~S}_{4}, \mathrm{~S}_{6}\right)$.

\section{Results and Discussion}

The different cationic compositions of water provided significant influence on transpiration $(E)$, stomatal conductance $(g s)$, internal $\mathrm{CO}_{2}$ concentration $(\mathrm{Ci})$ and $\mathrm{CO}_{2}$ assimilation rate $(A)$ of the castor bean cv. BRS Energia, at 100 days after sowing (Table 1). 
Table 1. Summary of analysis of variance for transpiration $(E)$, stomatal conductance $(g s)$, internal $\mathrm{CO}_{2}$ concentration $(\mathrm{Ci})$ and $\mathrm{CO}_{2}$ assimilation rate $(A)$ of castor bean plants, cv. 'BRS Energia', irrigated with waters of different cationic compositions, at 100 days after sowing

\begin{tabular}{|c|c|c|c|c|c|}
\hline \multirow{2}{*}{ Source of variation/Contrasts ${ }^{\#}$} & \multirow{2}{*}{$\mathrm{DF}$} & \multicolumn{4}{|c|}{ Mean squares } \\
\hline & & $g s$ & $E$ & $C i$ & $A$ \\
\hline Blocks & 3 & $0.51^{\mathrm{ns}}$ & $0.67^{\text {ns }}$ & $2738.58^{\mathrm{ns}}$ & $11.66^{\mathrm{ns}}$ \\
\hline Cationic compositions & (5) & $0.65^{*}$ & $1.24^{* *}$ & $21742.90^{* *}$ & $57.34^{* *}$ \\
\hline$\hat{\mathrm{y}}_{1}$ & 1 & $2.38^{*}$ & $3.88^{* *}$ & $47388.55^{* *}$ & $85.21^{*}$ \\
\hline$\hat{\mathrm{y}}_{2}$ & 1 & $0.007^{\mathrm{ns}}$ & $0.04^{\mathrm{ns}}$ & $9660.56^{*}$ & $1.86^{\mathrm{ns}}$ \\
\hline$\hat{\mathrm{y}}_{3}$ & 1 & $0.15^{\mathrm{ns}}$ & $0.09^{\mathrm{ns}}$ & $17578.12^{*}$ & $16.79^{\mathrm{ns}}$ \\
\hline$\hat{\mathrm{y}}_{4}$ & 1 & $0.15^{\mathrm{ns}}$ & $1.42^{*}$ & $57347.66^{* *}$ & $112.57^{*}$ \\
\hline$\hat{\mathrm{y}}_{5}$ & 1 & $0.11^{\mathrm{ns}}$ & $1.94^{*}$ & $42381.43^{* *}$ & $164.50^{\prime}$ \\
\hline Residual & 15 & 0.11 & 0.07 & 1624.20 & 10.68 \\
\hline $\mathrm{CV}(\%)$ & & 12.06 & 11.96 & 19.68 & 19.41 \\
\hline
\end{tabular}

Note. DF: Degree of freedom; CV: Coefficient of variation; $\left(^{*}\right)$ and $(* *)$ Significant at 0.05 and 0.01 probability levels, respectively; (ns) Not significant.

Stomatal conductance (Figure 1A) was significantly different among the different cationic compositions of the water, and its highest values ( 1.34 and $0.67 \mathrm{~mol}$ of $\left.\mathrm{H}_{2} \mathrm{O} \mathrm{m}^{-2} \mathrm{~s}^{-1}\right)$ were found in treatments irrigated with low-salinity water (Control) and high-salinity water containing $\mathrm{K}^{+}$, respectively, statistically differing from the other treatments $\left(\mathrm{S}_{2} ; \mathrm{S}_{3} ; \mathrm{S}_{4}\right.$ and $\left.\mathrm{S}_{6}\right)$, which had $g s$ values less than $0.48 \mathrm{~mol} \mathrm{of} \mathrm{H}_{2} \mathrm{O} \mathrm{m}^{-2} \mathrm{~s}^{-1}$. Due to the superiority of $g_{s}$ data in the treatment $\mathrm{S}_{5}$ (Figure 1A) compared with the other types of salts $\left(\mathrm{S}_{2}\right.$ and $\left.\mathrm{S}_{3}\right)$, it can be noted that, when 'BRS Energia' castor bean plants were irrigated with water containing $\mathrm{K}^{+}$, the degenerative effect caused by salinity was smaller.

The analysis of the contrasts for gs (Table 1) demonstrates the occurrence of significant effects only in the comparison between plants subjected to irrigation water with $\mathrm{ECw}$ of $0.6 \mathrm{dS} \mathrm{m}^{-1}\left(\mathrm{~S}_{1}\right)$ and those receiving water with $\mathrm{ECW}$ of $4.5 \mathrm{dS} \mathrm{m}{ }^{-1}\left(\mathrm{~S}_{2} ; \mathrm{S}_{3} ; \mathrm{S}_{4} ; \mathrm{S}_{5}\right.$ and $\left.\mathrm{S}_{6}\right)$. According to the mean estimation (Table 2), stomatal conductance was $0.84 \mathrm{~mol}$ of $\mathrm{H}_{2} \mathrm{O} \mathrm{m}^{-2} \mathrm{~s}^{-1}$ higher in plants irrigated with low-salinity water $\left(0.6 \mathrm{dS} \mathrm{m}^{-1}\right)$ at 100 DAS.
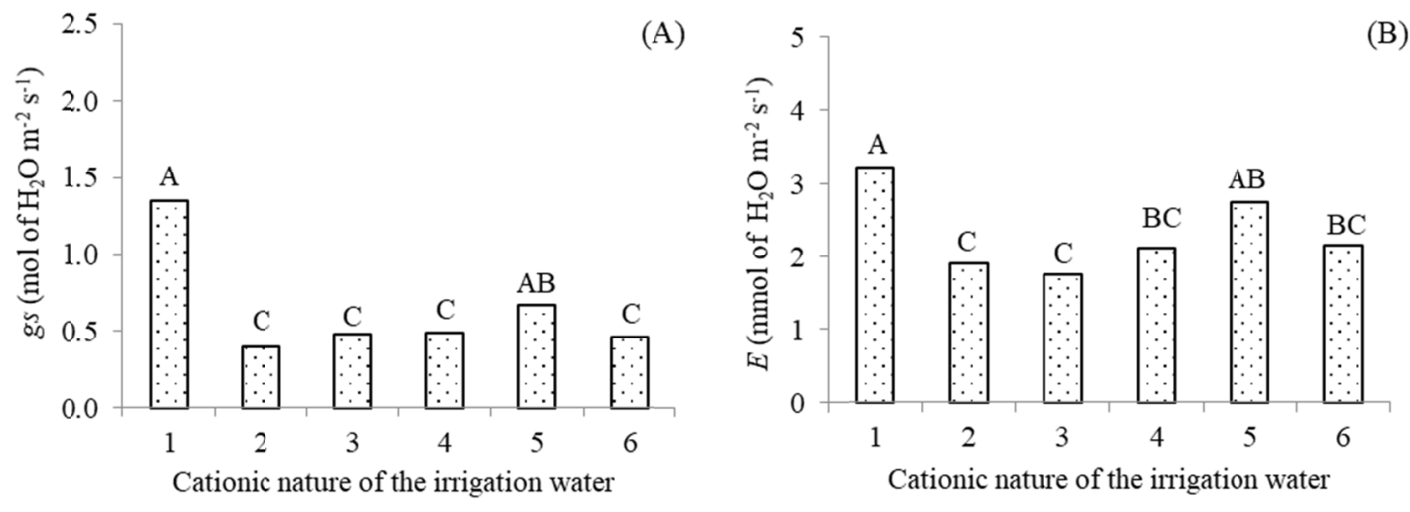

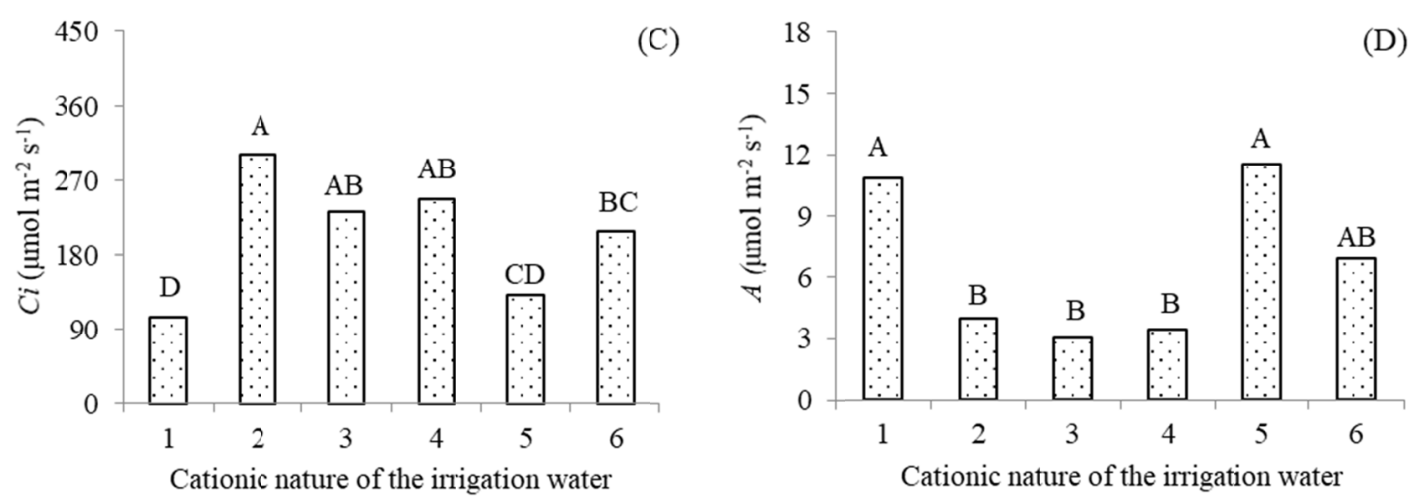

Figure 1. Stomatal conductance- $g s(\mathrm{~A})$, transpiration- $E(\mathrm{~B})$, internal $\mathrm{CO}_{2}$ concentration- $\mathrm{Ci}(\mathrm{C})$ and $\mathrm{CO}_{2}$ assimilation rate- $A$ (D) of castor bean, cv. 'BRS Energia', as a function of different cationic compositions and electrical conductivity, at 100 days after sowing

Note. $1=$ Control; $2=\mathrm{Na}+; 3=\mathrm{Ca}^{2+} ; 4=\mathrm{Na}^{+}+\mathrm{Ca}^{2+} ; 5=\mathrm{K}^{+} ; 6=\mathrm{Na}^{+}+\mathrm{Ca}^{2+}+\mathrm{Mg}^{2+}$; Means followed by different letters differ by Tukey test $(\mathrm{p}<0.05)$.

Thus, based on the results obtained, it can be inferred that the use of water of $\mathrm{ECw}=4.5 \mathrm{dS} \mathrm{m}^{-1}$ with different cationic compositions behaves similarly with $g s$. Therefore, the greatest effect is attributed to the variation of osmotic potential in the soil solution, caused by the different levels of electrical conductivity of water (ECw of 0.6 and $4.5 \mathrm{dS} \mathrm{m}^{-1}$ ). The stomatal closure observed in the present study through the reduction of stomatal conductance in plants irrigated with saline waters is related to the alteration in the osmotic potential and, consequently, to the reduction in water availability in their tissues, a situation which limits $\mathrm{CO}_{2}$ entry into the cells. Additionally, such limitation may increase the susceptibility to photochemical damages, because excess light energy in photosystem II is caused by low $\mathrm{CO}_{2}$ assimilation rates (Zheng et al., 2014).

Based on the means comparison test for transpiration (Figure 1B), castor bean plants in the treatment $\mathrm{S}_{1}$ (Control) did not differ statistically from those irrigated with saline water containing $\mathrm{K}^{+}\left(\mathrm{S}_{5}\right)$, but differed significantly from $\mathrm{S}_{2}, \mathrm{~S}_{3}, \mathrm{~S}_{4}$ and $\mathrm{S}_{6}$ and there were no significant differences among the treatments $\mathrm{S}_{4}, \mathrm{~S}_{5}$ and $\mathrm{S}_{6}$. Sousa Júnior et al. (2017), evaluating the effects of irrigation using waters of different cationic compositions (ECW of 0.5 and $5.0 \mathrm{dS} \mathrm{m}^{-1}$ ) on sunflower, cv. 'BRS 324', at 56 days after transplanting, observed reduction in gas exchanges regardless of the type of cation present in the irrigation water.

According to the contrasts of means obtained for leaf transpiration (Table 1), there were significant differences in $\mathrm{S}_{1}$ vs. $\mathrm{S}_{2}, \mathrm{~S}_{3}, \mathrm{~S}_{4}, \mathrm{~S}_{5}, \mathrm{~S}_{6} ; \mathrm{S}_{2} v s . \mathrm{S}_{5}$; and $\mathrm{S}_{5} v s . \mathrm{S}_{2} ; \mathrm{S}_{3} ; \mathrm{S}_{4} ; \mathrm{S}_{6}$. When plants irrigated with water of low ECw $(0.6$ $\left.\mathrm{dS} \mathrm{m} \mathrm{m}^{-1}\right)$ were compared with those subjected to the higher salinity level $\left(\mathrm{ECW}=4.5 \mathrm{dS} \mathrm{m}^{-1}\right)$ by the mean estimation (Table 2), the mean $E$ in the former was $1.07 \mathrm{mmol}^{\circ} \mathrm{H}_{2} \mathrm{O} \mathrm{m}^{-2} \mathrm{~s}^{-1}$ higher. For plants irrigated with water containing $\mathrm{Na}^{+}\left(\mathrm{S}_{2}\right)$, the $E$ was on average $0.84 \mathrm{mmol}$ of $\mathrm{H}_{2} \mathrm{O} \mathrm{m}^{-2} \mathrm{~s}^{-1}$ lower than that in plants subjected to water containing $\mathrm{K}^{+}$, respectively, indicating greater deleterious effect of $\mathrm{Na}^{+}$on castor bean leaf transpiration, at 100 days after sowing.

Castor bean plants irrigated using water containing $\mathrm{K}^{+}$also had higher $E$ than the other treatments of high-salinity waters $\left(\mathrm{S}_{2} ; \mathrm{S}_{3} ; \mathrm{S}_{4}\right.$ and $\left.\mathrm{S}_{6}\right)$, on average $0.77 \mathrm{mmol}$ of $\mathrm{H}_{2} \mathrm{O} \mathrm{m}^{-2} \mathrm{~s}^{-1}$. It is probable that the greater leaf transpiration obtained in the castor bean plants under irrigation with water of potassium composition is related to the functions that this element exerts in the establishment of the osmotic and ionic homeostasis, participating in the stomatal closure and opening, thus contributing to the maintenance of high water potential in the tissues of the plant, reflecting in greater cellular turgescence (Gurgel et al., 2010). 
Table 2. Mean estimation for transpiration $(E)$, stomatal conductance $(g s)$, internal $\mathrm{CO}_{2}$ concentration $(C i)$ and $\mathrm{CO}_{2}$ assimilation rate $(A)$ of castor bean plants, cv. 'BRS Energia', irrigated with waters of different cationic compositions and electrical conductivity, at 100 days after sowing

\begin{tabular}{lllll}
\hline \multirow{2}{*}{ Contrasts } & \multicolumn{4}{c}{ Mean estimation } \\
\cline { 2 - 5 } & $E$ & $g s$ & $C i$ & $A$ \\
\hline$\hat{\mathrm{y}}_{1}$ & 1.07 & 0.84 & -119.23 & 5.05 \\
$\hat{\mathrm{y}}_{2}$ & $\mathrm{~ns}$ & $\mathrm{~ns}$ & 69.50 & $\mathrm{~ns}$ \\
$\hat{\mathrm{y}}_{3}$ & $\mathrm{~ns}$ & $\mathrm{~ns}$ & 93.75 & $\mathrm{~ns}$ \\
$\hat{\mathrm{y}}_{4}$ & -0.84 & $\mathrm{~ns}$ & 169.33 & -7.50 \\
$\hat{\mathrm{y}}_{5}$ & 0.77 & $\mathrm{~ns}$ & -115.08 & 7.17 \\
\hline
\end{tabular}

Note. (ns) Not significant; $\hat{\mathrm{y}}_{1}\left(\mathrm{~S}_{1}\right.$ vs. $\left.\mathrm{S}_{2} ; \mathrm{S}_{3} ; \mathrm{S}_{4} ; \mathrm{S}_{5} ; \mathrm{S}_{6}\right) ; \hat{\mathrm{y}}_{2}\left(\mathrm{~S}_{2} v s . \mathrm{S}_{3}\right) ; \hat{\mathrm{y}}_{3}\left(\mathrm{~S}_{2} v s . \mathrm{S}_{6}\right) ; \hat{\mathrm{y}}_{4}\left(\mathrm{~S}_{2} v s . \mathrm{S}_{5}\right) ; \hat{\mathrm{y}}_{5}\left(\mathrm{~S}_{5} v s . \mathrm{S}_{2} ; \mathrm{S}_{3}\right.$; $\left.\mathrm{S}_{4} ; \mathrm{S}_{6}\right)$; Subscripts $1,2,3,4,5$ and 6 represent, respectively, the waters $\mathrm{S}_{1}=$ Control $\left(\mathrm{ECW}=0.6 \mathrm{dS} \mathrm{m} \mathrm{m}^{-1}\right) ; \mathrm{S}_{2}=$ $\mathrm{Na}^{+} ; \mathrm{S}_{3}=\mathrm{Ca}^{2+} ; \mathrm{S}_{4}=\mathrm{Na}^{+}+\mathrm{Ca}^{2+} ; \mathrm{S}_{5}=\mathrm{K}^{+} ; \mathrm{S}_{6}=\mathrm{Na}^{+}+\mathrm{Ca}^{2+}+\mathrm{Mg}^{2+} . \mathrm{S}_{2}, \mathrm{~S}_{3}, \mathrm{~S}_{4}, \mathrm{~S}_{5}$ and $\mathrm{S}_{6}\left(\mathrm{ECW}=4.5 \mathrm{dS} \mathrm{m} \mathrm{m}^{-1}\right)$.

With regard to internal $\mathrm{CO}_{2}$ concentration (Figure 1C), it was observed that castor bean plants irrigated with water containing $\mathrm{Na}^{+}\left(\mathrm{S}_{2}\right)$ were significantly different from those subjected to the control treatment $(\mathrm{ECW}=0.6$

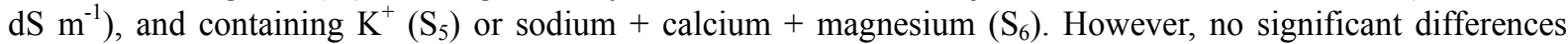
were observed in plants irrigated with water containing sodium $\left(\mathrm{S}_{2}\right)$, calcium $\left(\mathrm{S}_{3}\right)$ and calcium $+\operatorname{sodium}\left(\mathrm{S}_{4}\right)$. The low internal $\mathrm{CO}_{2}$ concentration observed in plants subjected to $\mathrm{S}_{1}$ and $\mathrm{S}_{5}$ possibly results from the higher values found for $\mathrm{CO}_{2}$ assimilation rate (Figure 1D).

According to the mean estimation for $\mathrm{Ci}$ (Table 2), it can be noted that when castor bean plants irrigated using water of lowest $\mathrm{ECW}$ level $\left(0.6 \mathrm{dS} \mathrm{m} \mathrm{m}^{-1}\right)$ there was a reduction of $119.23 \mu \mathrm{mol} \mathrm{m}^{-2} \mathrm{~s}^{-1}$ in $C i$, at $100 \mathrm{DAS}$, in comparison to those subjected to ECW of $4.5 \mathrm{dS} \mathrm{m}{ }^{-1}\left(\mathrm{~S}_{2} ; \mathrm{S}_{3} ; \mathrm{S}_{4} ; \mathrm{S}_{5}\right.$ and $\left.\mathrm{S}_{6}\right)$. However, in plants irrigated with saline water containing $\mathrm{Na}^{+}\left(\mathrm{S}_{2}\right) C i$ increased by $69.50,93.75$ and $169.33 \mu \mathrm{mol} \mathrm{m} \mathrm{m}^{-2} \mathrm{~s}^{-1}$, respectively, in comparison to the treatments $\mathrm{S}_{3}, \mathrm{~S}_{6}$ and $\mathrm{S}_{5}$.

On the other hand, comparing plants irrigated using water containing $\mathrm{K}^{+}\left(\mathrm{S}_{5}\right)$ with the other cations present in the irrigation water $\left(\mathrm{S}_{2} ; \mathrm{S}_{3} ; \mathrm{S}_{4}\right.$ and $\left.\mathrm{S}_{6}\right), C i$ decreased by $115.08 \mu \mathrm{mol} \mathrm{m} \mathrm{m}^{-2} \mathrm{~s}^{-1}$. The higher internal $\mathrm{CO}_{2}$ concentration found in the castor bean plants irrigated with $\mathrm{S}_{2}, \mathrm{~S}_{3} ; \mathrm{S}_{4}$ and $\mathrm{S}_{6}$ water, is an indication that the carbon fixed in the substomatic camera was not being used in the synthesis of photoassimilates or may be associated to the changes in the kinetics of the enzyme Ribulose 1,5-bisphosphatocarboxylase oxidase in the carbon metabolism due to the sensitivity to the accumulation of salts in the leaves, especially $\mathrm{Na}^{+}$and $\mathrm{Cl}^{-}$(Habermann et al., 2003).

Regarding the $\mathrm{CO}_{2}$ assimilation rates (Figure 1D), plants irrigated using water with the lowest saline level ( $\left.\mathrm{S}_{1}\right)$ and saline water containing $\mathrm{K}^{+}\left(\mathrm{S}_{5}\right)$ were significantly different from those subjected to the treatments $\mathrm{S}_{2}, \mathrm{~S}_{3}$ and $\mathrm{S}_{4}$. However, there was no difference in plants under treatment $\mathrm{S}_{6}$ and $\mathrm{S}_{2}, \mathrm{~S}_{3}$ and $\mathrm{S}_{4}$.

As observed for $E$, the analysis of contrasts (Table 1) showed significant effects on $\mathrm{CO}_{2}$ assimilation rate in the comparison between plants irrigated using water with ECw of $0.6 \mathrm{dS} \mathrm{m}^{-1}\left(\mathrm{~S}_{1}\right)$ and plants subjected to $4.5 \mathrm{dS} \mathrm{m}^{-1}$ $\left(\mathrm{S}_{2} ; \mathrm{S}_{3} ; \mathrm{S}_{4} ; \mathrm{S}_{5}\right.$ and $\left.\mathrm{S}_{6}\right)$. The mean estimation (Table 2) demonstrates the superiority of $A$ in plants irrigated with $0.6 \mathrm{dS} \mathrm{m}^{-1}$ water (mean value of $\left.5.05 \mu \mathrm{mol} \mathrm{m} \mathrm{s}^{-1}\right)$ in comparison to those subjected to ECw of $4.5 \mathrm{dS} \mathrm{m}{ }^{-1}\left(\mathrm{~S}_{2} ; \mathrm{S}_{3}\right.$; $\mathrm{S}_{4} ; \mathrm{S}_{5}$ and $\mathrm{S}_{6}$ ). When plants were irrigated using water prepared with $\mathrm{Na}^{+}\left(\mathrm{S}_{2}\right)$, there was a reduction in $A$ of 7.5 $\mu \mathrm{mol} \mathrm{m} \mathrm{m}^{-2} \mathrm{~s}^{-1}$ in comparison to those receiving water containing $\mathrm{K}^{+}\left(\mathrm{S}_{5}\right)$. Additionally, when irrigation was performed using saline water containing $\mathrm{K}^{+}\left(\mathrm{S}_{5}\right)$ (Table 2), there was an increase of $7.17 \mu \mathrm{mol} \mathrm{m}^{-2} \mathrm{~s}^{-1}$ in $\mathrm{CO}_{2}$ assimilation rate compared with plants subjected to the other cationic compositions $\left(\mathrm{S}_{2} ; \mathrm{S}_{3} ; \mathrm{S}_{4}\right.$ and $\left.\mathrm{S}_{6}\right)$ of high salinity.

The decline observed in the $\mathrm{CO}_{2}$ assimilation rate, especially in plants irrigated using water containing sodium, calcium, sodium + calcium and sodium + calcium + magnesium, may have resulted from the reduction in the amount of water absorbed and fixation of $\mathrm{CO}_{2}$ by the plant due to stomatal closure (Figure 1A), due to decrease in the osmotic potential of the soil caused by the increase in $\mathrm{ECW}$ since water and $\mathrm{CO}_{2}$ are two of the main limiting factors of photosynthesis, highlighting that higher diffusive resistance of the stomata reduces photosynthesis, especially by limiting gas conduction in the leaves (Kerbauy, 2008).

The plant height (PH), stem diameter (SD) and leaf area (LA) of the castor bean varied significantly $(\mathrm{p}<0.01)$ between the different cationic compositions of irrigation water (Table 3). Cavalcanti et al. (2005) in research 
with the castor bean cv. BRS 149 Nordestina, observed the significant influence of the ionic combinations of $\mathrm{Na}^{+}+\mathrm{Ca}^{2+}$ of the irrigation water, only for plant height, at 80 DAS.

Table 3. Summary of analysis of variance for plant height (PH), stem diameter (SD) and leaf area (LA) of castor bean cv. 'BRS Energia' irrigated with waters of different cationic compositions and electrical conductivity, at 100 days after sowing

\begin{tabular}{lllll}
\hline \multirow{2}{*}{ Source of variation/Contrasts } & \multirow{2}{*}{ DF } & Mean squares & \\
\cline { 3 - 5 } & & PH & SD & LA \\
\hline Blocks & 3 & $15.34^{\text {ns }}$ & $19.72^{\text {ns }}$ & $969402.08^{\text {ns }}$ \\
Cationic compositions & $(5)$ & $606.72^{* *}$ & $78.48^{* *}$ & $63740344.76^{* *}$ \\
$\hat{y}_{1}$ & 1 & $2640.47^{* *}$ & $248.26^{* *}$ & $306891072.90^{* *}$ \\
$\hat{y}_{2}$ & 1 & $0.24^{\text {ns }}$ & $1.47^{\text {ns }}$ & $821105.74^{\text {ns }}$ \\
$\hat{y}_{3}$ & 1 & $37.41^{\text {ns }}$ & $1.05^{\text {ns }}$ & $78739.60^{\text {ns }}$ \\
$\hat{y}_{4}$ & 1 & $296.46^{*}$ & $79.94^{* *}$ & $5776763.65^{*}$ \\
$\hat{y}_{5}$ & 1 & $344.03^{* *}$ & $124.84^{* *}$ & $9898432.13^{* *}$ \\
Residual & 15 & 18.79 & 3.69 & 297252.20 \\
CV $(\%)$ & & 7.39 & 10.09 & 15.17 \\
\hline
\end{tabular}

Note. DF: Degree of freedom; CV: Coefficient of variation; $\left({ }^{*}\right)$ and $\left({ }^{* *}\right)$ Significant at 0.05 and 0.01 probability levels, respectively; (ns) Not significant.

According to the means comparison test for plant height (Figure 2A), the values were significantly higher in castor bean plants irrigated with low-salinity water $\left(S_{1}\right)$ than in plants subjected to the treatments $S_{2}, S_{3}, S_{4}, S_{5}$ and $\mathrm{S}_{6}$, of high salinity. However, comparing $\mathrm{PH}$ as a function the different cationic compositions of the water (Figure $2 \mathrm{~A}$ ), there was significant effect only on plants subjected to irrigation with water containing $\mathrm{K}^{+}\left(\mathrm{S}_{5}\right)$ in relation to those receiving $\mathrm{S}_{2}$ and $\mathrm{S}_{3}$. There was no significant difference in the $\mathrm{PH}$ of castor bean plants subjected to the treatments $S_{2}, S_{3}, S_{4}$ and $S_{6}$.

For stem diameter, the means comparison test (Figure 2B) showed that plants irrigated with waters of low salinity $\left(\mathrm{S}_{1}\right)$ and containing $\mathrm{K}^{+}\left(\mathrm{S}_{5}\right)$ had higher SD compared with the other treatments $\left(\mathrm{S}_{2} ; \mathrm{S}_{3} ; \mathrm{S}_{4}\right.$ and $\left.\mathrm{S}_{6}\right)$, which did not differ significantly from one another. Alves et al. (2012), evaluating the effects of irrigation with saline water prepared by the dissolution of $\mathrm{NaCl}$ ( $\mathrm{ECw}$ from 0.6 to $4.6 \mathrm{dS} \mathrm{m}^{-1}$ ) on the growth of 'BRS Energia' castor bean, observed reduction in stem diameter of $6.53 \%$ per unit increase in ECw, at 40 DAS.
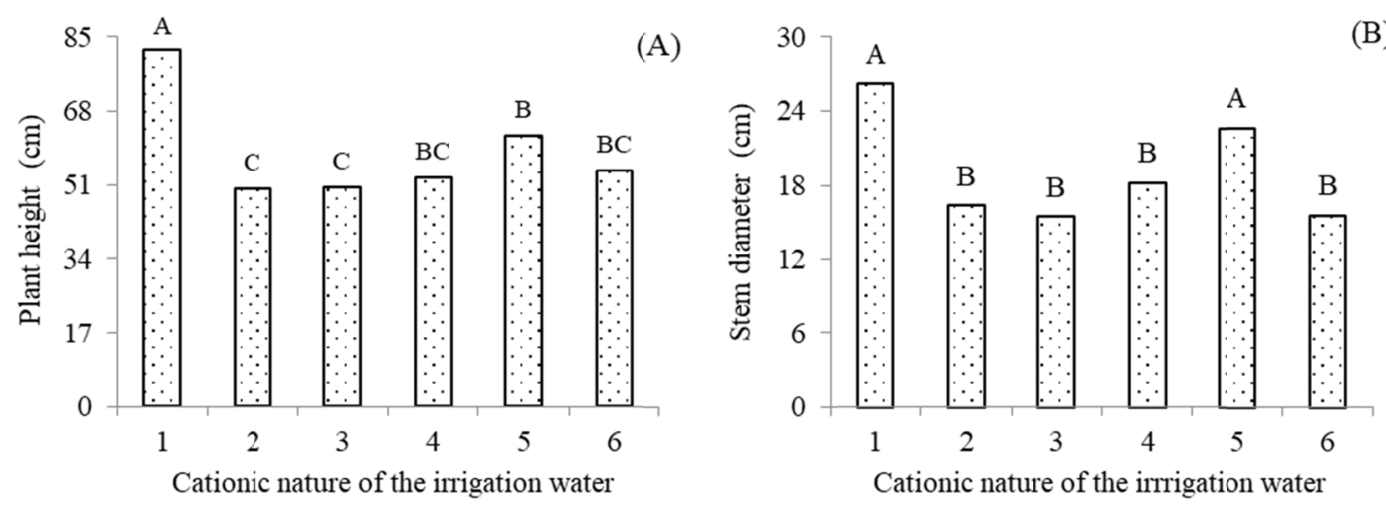


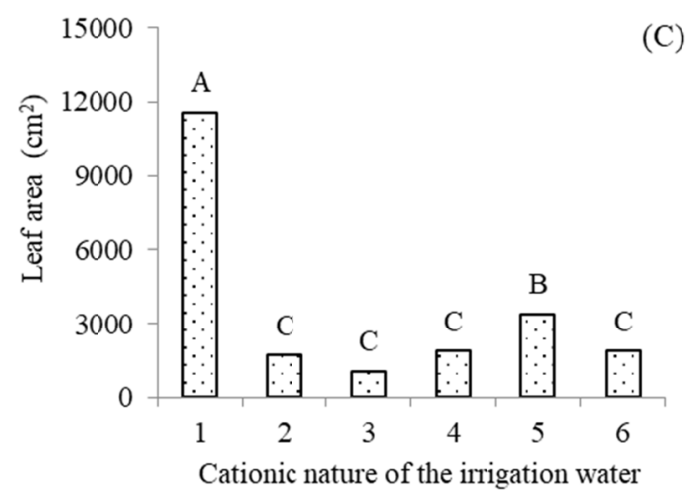

Figure 2. Plant height (A), stem diameter (B) and leaf area (A) of castor bean cv. 'BRS Energia' as a function of different cationic compositions and electrical conductivity of the irrigation water, at 100 days after sowing

Note. $1=$ Control; $2=\mathrm{Na}^{+} ; 3=\mathrm{Ca}^{2+} ; 4=\mathrm{Na}^{+}+\mathrm{Ca}^{2+} ; 5=\mathrm{K}^{+} ; 6=\mathrm{Na}^{+}+\mathrm{Ca}^{2+}+\mathrm{Mg}^{2+} ;$ Means followed by different letters differ by Tukey test $(\mathrm{p}<0.05)$.

Castor bean leaf area (Figure 2C) was significantly different between the control $\left(\mathrm{S}_{1}\right)$ and the other treatments $\left(\mathrm{S}_{2} ; \mathrm{S}_{3} ; \mathrm{S}_{4} ; \mathrm{S}_{5}\right.$ and $\left.\mathrm{S}_{6}\right)$. Among the saline waters with different cationic compositions $\left(\mathrm{S}_{2} ; \mathrm{S}_{3} ; \mathrm{S}_{4} ; \mathrm{S}_{5}\right.$ and $\left.\mathrm{S}_{6}\right)$, plants irrigated with saline water containing $\mathrm{K}^{+}\left(\mathrm{S}_{5}\right)$ showed statistically higher LA in comparison to others. Under salt stress conditions, morphological alterations commonly occur in plants, which leads to reduction of transpiration as an alternative to maintain equilibrium with low absorption of saline water, and these adaptations include the reduction in leaf expansion (Oliveira et al., 2010). This result is consistent with the leaf transpiration data (Figure 1B), since plants irrigated using low-salinity water or containing $\mathrm{K}^{+}$showed the highest values of $E$.

Based on the summary of analysis of variance for the contrasts of means relative to PH, SD and LA (Table 3), there was significant effect of the different treatments on all variables analyzed. According to the mean estimation (Table 4), it can be noted that plants subjected to the low level of water salinity $\left(0.6 \mathrm{dS} \mathrm{m} \mathrm{m}^{-1}\right) \mathrm{had}$ increments of $28.14 \mathrm{~cm}, 8.63 \mathrm{~mm}$ and $9595.17 \mathrm{~cm}^{2}$, respectively, in PH, SD and LA, in comparison to those subjected to ECw of $4.5 \mathrm{dS} \mathrm{m}^{-1}\left(\mathrm{~S}_{2} ; \mathrm{S}_{3} ; \mathrm{S}_{4} ; \mathrm{S}_{5} ; \mathrm{S}_{6}\right)$.

Probably, the reduction of PH, SD and LA in plants cultivated at the higher level of water salinity $(\mathrm{ECW}=4.5 \mathrm{dS}$ $\mathrm{m}^{-1}$ ) results from the osmotic effect of the dissolved salts, which reduces the osmotic potential of the soil solution and inhibits the transport of water to the cells, characterizing the water stress on plants (Flowers, 2004).

Table 4. Mean estimation for plant height (PH), stem diameter (SD) and leaf area (LA) of castor bean cv. 'BRS Energia' irrigated with waters of different cationic compositions and electrical conductivity, at 100 days after sowing

\begin{tabular}{llll}
\hline \multirow{2}{*}{ Contrasts } & \multicolumn{3}{c}{ Mean estimation } \\
\cline { 2 - 4 } & PH $(\mathrm{cm})$ & SD $(\mathrm{mm})$ & $\mathrm{LA}\left(\mathrm{cm}^{2}\right)$ \\
\hline$\hat{\mathrm{y}}_{1}$ & 28.14 & 8.63 & 9595.17 \\
$\hat{\mathrm{y}}_{2}$ & $\mathrm{~ns}$ & $\mathrm{~ns}$ & $\mathrm{~ns}$ \\
$\hat{\mathrm{y}}_{3}$ & $\mathrm{~ns}$ & $\mathrm{~ns}$ & $\mathrm{~ns}$ \\
$\hat{\mathrm{y}}_{4}$ & -12.17 & -6.32 & -1699.52 \\
$\hat{\mathrm{y}}_{5}$ & 10.36 & 6.24 & 1758.76 \\
\hline
\end{tabular}

Note. (ns) Not significant; $\hat{\mathrm{y}}_{1}\left(\mathrm{~S}_{1} v s . \mathrm{S}_{2} ; \mathrm{S}_{3} ; \mathrm{S}_{4} ; \mathrm{S}_{5} ; \mathrm{S}_{6}\right) ; \hat{\mathrm{y}}_{2}\left(\mathrm{~S}_{2} v s . \mathrm{S}_{3}\right) ; \hat{\mathrm{y}}_{3}\left(\mathrm{~S}_{2} v s . \mathrm{S}_{6}\right) ; \hat{\mathrm{y}}_{4}\left(\mathrm{~S}_{2} v s . \mathrm{S}_{5}\right) ; \hat{\mathrm{y}}_{5}\left(\mathrm{~S}_{5} v s . \mathrm{S}_{2} ; \mathrm{S}_{3}\right.$; $\left.\mathrm{S}_{4} ; \mathrm{S}_{6}\right)$; Subscripts 1, 2, 3, 4, 5 and 6 represent the waters $\mathrm{S}_{1}=$ Control $\left(\mathrm{ECW}=0.6 \mathrm{dS} \mathrm{m}{ }^{-1}\right) ; \mathrm{S}_{2}=\mathrm{Na}^{+} ; \mathrm{S}_{3}=\mathrm{Ca}^{2+} ;$ $\mathrm{S}_{4}=\mathrm{Na}^{+}+\mathrm{Ca}^{2+} ; \mathrm{S}_{5}=\mathrm{K}^{+} ; \mathrm{S}_{6}=\mathrm{Na}^{+}+\mathrm{Ca}^{2+}+\mathrm{Mg}^{2+} . \mathrm{S}_{2}, \mathrm{~S}_{3}, \mathrm{~S}_{4}, \mathrm{~S}_{5}$ and $\mathrm{S}_{6}\left(\mathrm{ECW}=4.5 \mathrm{dS} \mathrm{m}^{-1}\right)$.

Based on the contrasts of means for the treatments $\mathrm{S}_{2} v s . \mathrm{S}_{3} ; \mathrm{S}_{2} v s . \mathrm{S}_{6}$ (Table 3), there was no significant effect on any of the variables evaluated. According to the mean estimation (Table 4), when water containing $\mathrm{Na}^{+}\left(\mathrm{S}_{2}\right)$ was used in irrigation, PH, SD and LA were significantly inferior, with decrease of $12.17 \mathrm{~cm}, 6.32 \mathrm{~mm}$ and 1699.52 $\mathrm{cm}^{2}$, respectively, in comparison to plants in the treatment $\mathrm{S}_{5}$. Comparing castor bean plants receiving water 
containing $\mathrm{K}^{+}$, there were increments of $10.36 \mathrm{~cm}, 6.24 \mathrm{~mm}$ and $1758.76 \mathrm{~cm}^{2}$ in $\mathrm{PH}, \mathrm{SD}$ and LA, respectively, in comparison to plants in the treatments $\mathrm{S}_{2}, \mathrm{~S}_{3}, \mathrm{~S}_{4}, \mathrm{~S}_{5}$ and $\mathrm{S}_{6}$. According to Melo et al. (2014), the accumulation of potassium in the plant favors the formation and translocation of carbohydrates and the efficient use of water by the plant; in addition, the supply of potassium in the soil solution can stimulate the greater uptake and assimilation of nitrogen and phosphorus and, consequently, promote greater plant growth.

\section{Conclusions}

Gas exchanges and growth of castor bean cv. 'BRS Energia' were more sensitive to the variation in electrical conductivity of water than to the variation in cationic nature, and the smallest deleterious effect was observed in the plants irrigated with water containing $\mathrm{K}^{+}$.

The plants irrigated with water of potassium composition obtained the highest values for stomatal conductance, transpiration and rate of assimilation of $\mathrm{CO}_{2}$; at 100 days after sowing,

The castor cv. BRS Energia shows sensitivity to the presence of sodium and calcium salts in irrigation water.

\section{References}

Alves, A. N., Gheyi, H. R., Uyeda, C. A., Soares, F. A. L., Nobre, R. G., \& Cardoso, J. A.F. (2012). Uso de águas salinas e adubação nitrogenada no cultivo da mamoneira BRS-Energia. Revista Brasileira de Agricultura Irrigada, 6(2), 151-163. https://doi.org/10.7127/rbai.v6n200218

Alves, M. S., Soares, T. M., Silva, L. T., Fernandes, J. P., Oliveira, M. L. A., \& Paz, V. P. S. (2011). Estratégias de uso de água salobra na produção de alface em hidroponia NFT. Revista Brasileira de Engenharia Agricola e Ambiental, 15(5), 491-498. https://doi.org/10.1590/S1415-43662011000500009

Cavalcanti, M. L. F., Fernandes, P. D., Gheyi, H. R., Barros Júnior, G., Soares, F. A. L., \& Siqueira, E. da C. (2005). Tolerância da mamoneira BRS 149 à salinidade: Germinação e características de crescimento. Revista Brasileira de Engenharia Agrícola e Ambiental, 9(Suplemento), 57-61.

Ferreira, D. F. (2011). Sisvar: A computer statistical analysis system. Ciência e Agrotecnologia, 35(6), 1039-1042. https://doi.org/10.1590/S1413-70542011000600001

Gurgel, M. T., Gheyi, H. R., \& Oliveira, F. H. T. (2010). Acúmulo de matéria seca e nutrientes em meloeiro produzido sob estresse salino e doses de potássio. Revista Ciência Agronômica, 41(1), 18-28. https://doi.org/10.5935/1806-6690.20100003

Habermann, G., Machado, E. C., Rodrigues, J. D., \& Medina, C. L. (2003). $\mathrm{CO}_{2}$ assimilation, photosynthetic light response curves, and water relations of 'Pêra' sweet orange plants infected with Xylella fastidious. Brazilian Journal of Plant Physiology, 15(2), 79-87. https://doi.org/10.1590/S1677-04202003000200003

Kerbauy, G. B. (2008). Fisiologia vegetal (2nd ed., p. 431). Rio de Janeiro: Guanabara Koogan.

Lima, G. S. de, Gheyi, H. R., Nobre, R. G., Xavier, D. A., Soares, L. A. dos A., \& Sousa, J. R. M. de. (2016). Morpho-physiology and oil yield of castor bean (Ricinus communis L.) as a function of salinity and the cationic nature of irrigation water. Australian Journal of Crop Science, 10(3), 402-410. https://doi.org/ 10.21475/ajcs.2016.10.03.p7246

Lima, G. S. de, Nobre, R. G., Gheyi, H. R., Soares, L. A. dos A., \& Silva, S. S. da. (2014b). Respostas morfofisiológicas da mamoneira, em função da salinidade da água de irrigação e adubação nitrogenada. Irriga, 19(1), 130-136.

Lima, G. S. de, Nobre, R. G., Gheyi, H. R., Soares, L. A. dos A., Lourenço, G. da S., \& Silva, S. S. da. (2014a). Aspectos de crescimento e produção da mamoneira irrigada com águas salinas e adubação nitrogenada. Revista Brasileira de Engenharia Agrícola e Ambiental, 18(6), 615-622.

Medeiros, J. F. de, Lisboa, R. de A., \& Oliveira, M. de. (2003). Caracterização das águas subterrâneas usadas para irrigação na área produtora de melão da Chapada do Apodi. Revista Brasileira de Engenharia Agrícola e Ambiental, 7(3), 469-472. https://doi.org/10.1590/S1415-43662003000300010

Melo, A. S., Silva Junior, C. D., Fernandes, P. D., Brito, M. E. B., Sobral, L. F., Suassuna, J. F., Ferraz, R. L. de S. (2014). Chlorophyll and macronutrients content in leaf tissue of Musa sp 'Prata-Anã' under fertigation. African Journal of Agricultural Research, 9(22), 1714-1720. https://doi.org/10.5897/AJAR2014.8683

Nobre, R. G., Gheyi, H. R., Soares, F. A. L., \& Cardoso, J. A. F. (2011). Produção de girassol sob estresse salino e adubação nitrogenada. Revista Brasileira de Ciência do Solo, 35(3), 929-937. https://doi.org/ $10.1590 / \mathrm{S} 0100-06832011000300027$ 
Nobre, R. G., Lima, G. S. de; Gheyi, H. R., Lourenço, G. S., \& Soares, L. A. A. (2013). Emergência, crescimento e produção da mamoneira sob estresse salino e adubação nitrogenada. Revista Ciência Agronômica, 44(1), 76-85. https://doi.org/10.1590/S1806-66902013000100010

Novais, R. F., Neves, J. C. L., \& Barros, N. F. (1991). Ensaio em ambiente controlado. In A. J. Oliveira (Ed.), Métodos de pesquisa em fertilidade do solo (pp. 189-253). Brasília: Embrapa-SEA.

Oliveira Filho, A. F. de, Oliveira, F. de A. de, Medeiros, J. F. de, Mesquita, T. de O., \& Zonta, E. (2010). Crescimento de cultivares de mamoneira sob doses de torta de mamona. Revista Verde de Agroecologia e Agricultura Sustentável, 5(5), 18-24.

Ribeiro, S., Chaves, L. H. G., Guerra, H. O. C., Gheyi, H. R., \& Lacerda, R. D. de. (2009). Resposta da mamoneira cultivar BRS-188 Paraguaçu à aplicação de nitrogênio, fósforo e potássio. Revista Ciência Agronômica, 40(4), 465-473.

Richards, L. A. (1954). Diagnosis and improvement of saline and alkali soils (p. 160). Washington: U. S. Department of Agriculture.

Santos, J. B. dos, Santos, D. B. dos, Azevedo, C. A. V. de, Rebequi, A. M., Cavalcante, L. F., \& Cavalcante, I. H. L. (2013). Comportamento morfofisiológico da mamoneira BRS Energia submetida à irrigação com água salina. Revista Brasileira de Engenharia Agrícola e Ambiental, 17(2), 145-1522. https://doi.org/ 10.1590/S1415-43662013000200005

Severino, L. S., Vale, L. S., Cardoso, G. D., Beltrão, N. E. de M., \& Santos, J. W. dos. (2005). Método para determinação da área foliar da mamoneira (p. 20). Campina Grande: Embrapa-CNPA.

Silva, L. B. da, \& Martins, C. C. (2009). Teste de condutividade elétrica para sementes de mamoneira. Semina: Ciências Agrárias, 30(Suppl. 1), 1043-1050.

Silva, S. D. da, Presotto, R. A., Marota, H. B., \& Zonta, E. (2012). Uso de torta de mamona como fertilizante orgânico. Pesquisa Agropecuária Tropical, 42(1), 19-27. https://doi.org/10.1590/S1983-4063201200010 0003

Silva, S. M. S., Gheyi, H. R., Beltrão, N. E. de M., Santos, J. W. dos, \& Soares, F. A. L. (2009). Dotações hídricas em densidades de plantas na cultura da mamoneira cv. BRS Energia. Revista Brasileira de Ciências Agrárias, 4(3), 338-348. https://doi.org/10.5039/agraria.v4i3a17

Sousa Júnior, J. R. de, Lima, G. S. de, Gheyi, H. R., Lima, V. L. A. de, Santos, J. B. dos, Sousa, J. R. M. de, \& Furtado, G. de F. (2017). Gas exchange and production of sunflower (Helianthus annuus L.) irrigated with water of different salinity, cationic nature and nitrogen doses. Australian Journal of Crop Science, 11(03), 300-307. https://doi.org/10.21475/ajcs.17.11.03.pne441

Zeng, W., Xu, C., Wu, J., Huang, J., Zhao, Q., \& Wu, M. (2014). Impacts of salinity and nitrogen on the photosynthetic rate and growth of sunflowers (Helianthus annuus L.). Pedosphere, 24(5), 635-344. https://doi.org/10.1016/S1002-0160(14)60049-7

\section{Copyrights}

Copyright for this article is retained by the author(s), with first publication rights granted to the journal.

This is an open-access article distributed under the terms and conditions of the Creative Commons Attribution license (http://creativecommons.org/licenses/by/4.0/). 